\title{
Inovasi Literasi Jaringan dalam Pendidikan Bahasa dan Sastra Indonesia di Masa Pandemi
}

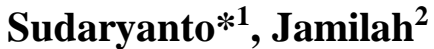 \\ e-mail: *1 sudaryanto@pbsi.uad.ac.id \\ ${ }^{1,2}$ Program Studi S-3 Ilmu Pendidikan Bahasa, Program Pascasarjana, \\ Universitas Negeri Yogyakarta
}

\begin{abstract}
Abstrak
Literasi jaringan digunakan oleh pihak Program Studi (Prodi) Pendidikan Bahasa dan Sastra Indonesia Fakultas Keguruan dan Ilmu Pendidikan Universitas Ahmad Dahlan dalam masa Belajar/Bekerja dari Rumah (BDR). Literasi itu dipakai sebagai media perkuliahan antara dosen dan mahasiswa, serta media akademik lainnya. Di masa pandemi Covid-19 ini, para dosen dan mahasiswa Program Studi Pendidikan Bahasa dan Sastra Indonesia melakukan sejumlah inovasi literasi jaringan. Jenis penelitian ini adalah kualitatif deskripsi. Data yang dianalisis adalah informasi dan praktik penggunaan literasi jaringan di lingkup Program Studi Pendidikan Bahasa dan Sastra Indonesia FKIP UAD, terutama pada semester genap TA 2019/2020. Hasil penelitian menunjukkan bahwa inovasi literasi jaringan terwujud ke dalam aktivitas perkuliahan, ujian skripsi, pengajian bagi dosen dan tenaga kependidikan, kegiatan pengabdian terhadap masyarakat, kegiatan kemahasiswaan, dan pemberian dukungan terhadap salah satu finalis Duta Bahasa Daerah Istimewa Yogyakarta 2020. Zoom, WhatsApp, dan Instagram dimanfaatkan dalam literasi jaringan terkait bidang pendidikan bahasa dan sastra Indonesia.
\end{abstract}

Kata kunci: inovasi, literasi jaringan, Pendidikan Bahasa dan Sastra Indonesia

\section{A. PENDAHULUAN}

Internet bisa menjadi langkah yang sangat positif untuk memajukan pendidikan, organisasi, dan partisipasi dalam masyarakat yang berarti. Demikian kata-kata Noam Chomsky, ahli bahasa dan aktivis politik dari Amerika Serikat. Kata-kata profesor linguistik dari Institut Teknologi Massachusetts (MIT), Amerika Serikat itu, benar. Di tengah masa pandemi Covid-19 ini, terutama sejak bulan Maret 2020 silam hingga sekarang, praktik perkuliahan di perguruan tinggi (PT) mengalami pergeseran, dari awalnya berbasis tatap muka berubah menjadi berbasis dalam jaringan (daring/online), atau dalam istilah Chomsky, "berbasis internet". Terkait itu, muncullah pertanyaan, bagaimana strategi pihak kampus (baca: dosen dan pengelola program studi) dalam mengantisipasi aktivitas perkuliahan dan non-perkuliahan dalam masa Belajar/Bekerja dari Rumah (BDR) di tengah masa pandemi Covid-19? 
Tulisan ini akan berfokus ke arah strategi inovasi literasi jaringan dalam bidang pendidikan bahasa dan sastra Indonesia di tengah masa pandemi Covid-19. Dalam konteks tulisan ini, penulis lebih menggunakan istilah "literasi jaringan" agar sesuai dengan Kamus Besar Bahasa Indonesia (KBBI) V, literasi jaringan, yaitu 'kemampuan untuk menggunakan, memahami, menemukan, dan memanipulasi informasi dalam jaringan, misalnya internet' atau istilah lainnya, literasi internet. Terkait itu, istilah "literasi jaringan" juga senada dengan istilah yang banyak digunakan oleh masyarakat saat ini, yaitu dalam jaringan (daring/online) dan luar jaringan (luring/offline).

Terkait itu pula, telah terbit sejumlah kajian tentang literasi digital dalam bidang pendidikan, bahasa, dan komunikasi, baik di Indonesia maupun di luar negeri, seperti Mustafa (2013), Riady (2013), Pattah (2014), Siyamitri (2015), Said (2016), Jordana \& Suwarto (2017), Subarjo (2017), Sudaryanto, dkk. (2018), Agustien, dkk. (2019), Anggraeni (2019), Rahayu, dkk. (2019), Herlandy \& Novalia (2019), Sudaryanto, dkk. (2019a), Sudaryanto, dkk. (2019b), dan Mulyono \& Ansori (2020). Dari kelima belas kajian itu, hanya ada dua kajian yang bersinggungan dengan bidang bahasa, terutama pembinaan bahasa Indonesia, yaitu Sudaryanto, dkk. (2019a) dan Sudaryanto, dkk. (2019b). Namun demikian, kedua kajian itu belum berfokus pada bidang pendidikan bahasa dan sastra Indonesia di tengah masa pandemi Covid-19.

Agar mudah dipahami oleh pembaca, maka tulisan ini akan berpijak pada praktik baik (best practice) strategi inovasi literasi jaringan pada bidang pendidikan bahasa dan sastra Indonesia di Program Studi S-1 Pendidikan Bahasa dan Sastra Indonesia Fakultas Keguruan dan Ilmu Pendidikan Universitas Ahmad Dahlan, Yogyakarta TA 2019/2020. Uraian tentang praktik baik itu akan dilengkapi dengan foto atau gambar pendukung yang relevan. Di bagian akhir tulisan ini akan diuraikan kesimpulan dan saran terkait strategi inovasi literasi jaringan pada bidang pendidikan bahasa dan sastra Indonesia.

\section{B. KAJIAN TEORI}

Setiap negara memiliki kebijakan bahasa atau politik bahasa masingmasing. Kridalaksana (2011: 197) menjelaskan bahwa politik bahasa adalah prinsip-prinsip dan langkah-langkah pelaksanaan pembinaan dan pengembangan 
bahasa yang dirumuskan sesuai dengan kepentingan nasional suatu negara. Politik bahasa biasanya disebarluaskan dalam bentuk undang-undang atau peraturan lain yang eksplisit dan mengikat. Dalam konteks Indonesia, ada Undang-Undang Dasar Negara Kesatuan Republik Indonesia Tahun 1945 dan Undang-Undang Republik Indonesia Nomor 24 Tahun 2009 tentang Bendera, Bahasa, dan Lambang Negara, serta Lagu Kebangsaan.

Di dalam Undang-Undang Dasar Negara Kesatuan Republik Indonesia Tahun 1945 disebutkan bahwa Bahasa Negara ialah Bahasa Indonesia (Pasal 36 ayat (1)). Kemudian di pasal berikutnya, Pasal 36C ayat (1), disebutkan bahwa ketentuan lebih lanjut mengenai Bendera, Bahasa, dan Lambang Negara, serta Lagu Kebangsaan diatur dengan undang-undang. Selanjutnya, di dalam UndangUndang Republik Indonesia Nomor 24 Tahun 2009 tentang Bendera, Bahasa, dan Lambang Negara, serta Lagu Kebangsaan. Dalam produk hukum itu, pada Pasal 29 ayat (1) disebutkan bahwa Bahasa Indonesia wajib digunakan sebagai bahasa pengantar dalam pendidikan nasional. Dari aturan-aturan hukum itu, disepakati adanya mata pelajaran Bahasa Indonesia di sekolah atau madrasah dari tingkat dasar (SD/MI), menengah pertama (SMP/MTs), hingga tingkat menengah atas (SMA/MA) dan menengah kejuruan (SMK), serta adanya program studi Pendidikan Bahasa (dan Sastra) Indonesia di PT.

Terkait itu, Badan Pengembangan dan Pembinaan Bahasa selaku lembaga yang memiliki otoritas di bidang kebahasaan dan kesastraan di Indonesia, memiliki empat program strategis terkait bidang bahasa Indonesia dalam kurun waktu empat tahun ke depan (2020-2024), yaitu (1) penguatan bahasa Indonesia sebagai bahasa pengantar pendidikan, (2) peningkatan fungsi bahasa Indonesia sebagai bahasa internasional, (3) peningkatan kemahiran membaca, menulis, dan berkomunikasi dalam bahasa Indonesia pada pendidikan keaksaraan, dan (4) fasilitasi program studi bahasa dan sastra Indonesia di SMA/MA dan perguruan tinggi. Butir nomor 1 dan 4 bersinggungan dengan bidang pendidikan bahasa dan sastra Indonesia di lingkungan PT, terutama dari segi akademik dan nonakademik. Dari segi akademik, adanya mata kuliah umum (MKU) Bahasa Indonesia berbobot 2-3 sistem kredit semester (SKS) di tiap-tiap program studi (Prodi) terkecuali Prodi PBSI/PBI, penggunaan bahasa Indonesia di tugas akhir skripsi dan publikasi ilmiah mahasiswa. Kemudian dari segi nonakademik, penggunaan 
bahasa Indonesia sebagai bahasa pengantar perkuliahan, rapat dosen/mahasiswa, pengajian dosen/mahasiswa, kegiatan promosi penerimaan mahasiswa baru (PMB) Prodi, dan dukungan terhadap salah satu finalis Duta Bahasa Provinsi Daerah Istimewa Yogyakarta.

\section{METODE PENELITIAN}

Penelitian ini tergolong ke dalam jenis penelitian kualitatif deskriptif. Deskripsi merupakan gambaran ciri-ciri data secara akurat dan sesuai dengan sifat alamiah data itu sendiri. Data yang dianalisis, yaitu strategi inovasi literasi jaringan dalam bidang pendidikan bahasa dan sastra Indonesia, khususnya di Program Studi Pendidikan Bahasa dan Sastra Indonesia Fakultas Keguruan dan Ilmu Pendidikan Universitas Ahmad Dahlan. Kemudian metode pengumpulan data yang digunakan adalah metode observasi dengan teknik baca dan catat.

Langkah selanjutnya, peneliti melakukan penyusunan dan kategorisasi. Menurut Moleong (1988: 140), kategorisasi merupakan langkah yang penting dan harus mengikuti aturan-aturan tertentu. Pertama, kategori harus berkaitan dengan tujuan penelitian. Kedua, kategori itu harus "tuntas", artinya setiap data dapat ditempatkan pada salah satu kategorinya. Ketiga, kategori harus "tidak saling bergantung", artinya tidak boleh ada satu pun isi data yang dapat masuk ke dalam lebih dari satu kategori. Keempat, kategori harus "bebas”. Kelima, kategori harus diperoleh atas dasar prinsip klasifikasi tunggal.

Keabsahan data dalam penelitian ini dilakukan dengan dua konsep, yaitu konsep kesahihan (validitas) dan konsep keterandalan (reliabilitas). Dalam penelitian ini, peneliti menggunakan validitas semantik dan reliabilitas melalui cara baca dan kaji ulang. Untuk memperoleh data yang terpercaya, peneliti melakukan tiga cara, yaitu (1) ketekunan pengamatan, (2) triangulasi, dan (3) pengecekan teman sejawat.

Triangulasi dalam penelitian ini berupa teknik triangulasi sumber, metode, dan teori. Menurut Patton (lewat Moleong, 1988: 151), triangulasi dengan sumber berarti membandingkan dan mengecek balik derajat kepercayaan sesuatu informasi yang diperoleh melalui waktu dan alat yang berbeda dalam metode kualitatif. Adapun teman sejawat dalam penelitian ini adalah Dr. Purwati Zisca Diana, M.Pd., dosen pada Program Studi Pendidikan Bahasa dan Sastra Indonesia 
Fakultas Keguruan dan Ilmu Pendidikan Universitas Ahmad Dahlan. Dia dipandang memiliki kemampuan yang baik di bidang pendidikan bahasa Indonesia.

\section{HASIL DAN PEMBAHASAN}

Bagian ini menguraikan hasil dan pembahasan mengenai strategi inovasi literasi jaringan dalam bidang pendidikan bahasa dan sastra Indonesia di tengah masa pandemi Covid-19. Secara singkat, inovasi literasi jaringan terwujud ke dalam aktivitas perkuliahan, ujian skripsi, pengajian bagi dosen dan tenaga kependidikan (tendik) di lingkungan UAD, kegiatan pengabdian terhadap masyarakat, kegiatan kemahasiswaan, dan pemberian dukungan terhadap salah satu finalis Duta Bahasa Provinsi Daerah Istimewa Yogyakarta tahun 2020. Terkait hal itu, inovasi literasi jaringan yang dilakukan di Program Studi Pendidikan Bahasa dan Sastra Indonesia Fakultas Keguruan dan Ilmu Pendidikan Universitas Ahmad Dahlan barangkali dapat dicontoh oleh prodi serupa di perguruan tinggi negeri (PTN) atau perguruan tinggi swasta (PTS).

Pertama, strategi inovasi literasi jaringan digunakan dalam aktivitas perkuliahan. Di dalam perkuliahan Fonologi Bahasa Indonesia, dosen pengampu membuat grup WhatsApp (WA) untuk para mahasiswanya. Melalui aplikasi media sosial itu, dosen pengampu membuat kuis sebanyak 10 soal dan para mahasiswa menjawab kuis tadi setelah membaca buku referensi perkuliahan, yaitu Fonetik karya Prof. Dr. Marsono, M.S., terbitan Gadjah Mada University Press, Yogyakarta. Selain itu, melalui WA pula mahasiswa menjawab soal ujian akhir semester (UAS) berupa perekaman bunyi vokal dan konsonan dalam bahasa Indonesia melalui menu voice note dalam WA. Kemudian dosen pengampu tinggal mengunduh berkas berupa voice note karya mahasiswa tadi. 


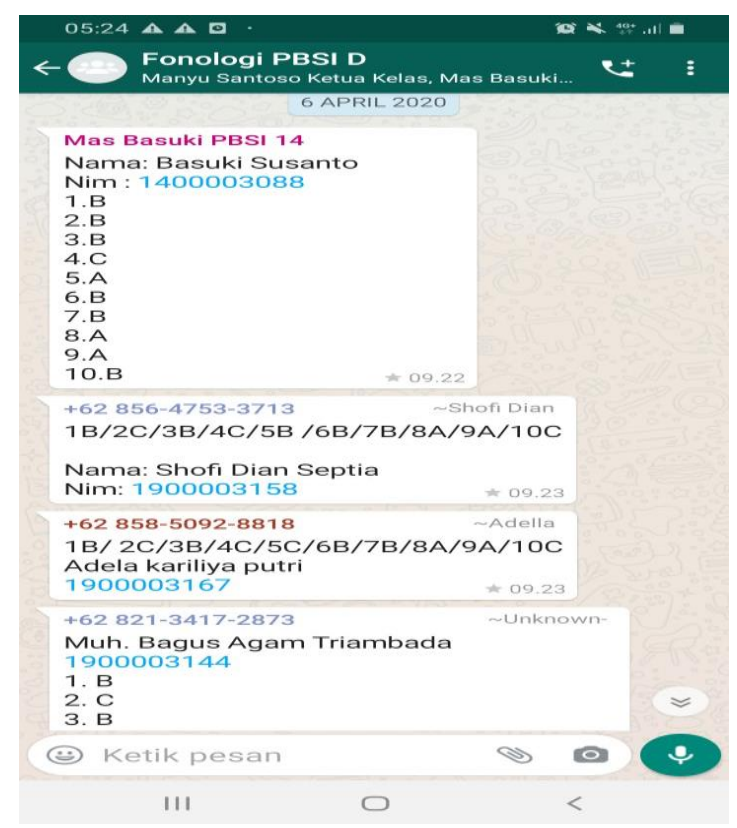

Gambar 1. Kuis dalam Grup WhatsApp Fonologi PBSI D

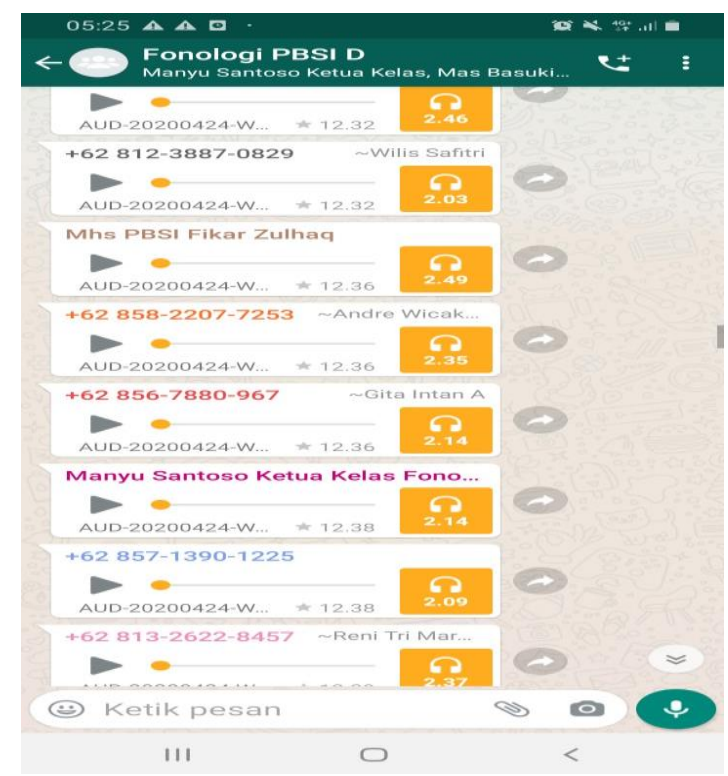

Gambar 2. Voice Note dalam Grup WhatsApp Fonologi PBSI D

Kedua, strategi inovasi literasi jaringan digunakan dalam ujian skripsi. Pihak pengelola program studi telah menawarkan aplikasi yang digunakan, yaitu Zoom, Google Meet, atau WA. Dosen pembimbing skripsi dan mahasiswa peserta ujian skripsi diberikan kesempatan untuk memilih terkait aplikasi yang digunakan saat ujian skripsi. Ada mahasiswa yang memiliki grup WA berisikan empat orang (ketua penguji, penguji 1, penguji 2, dan mahasiswa). Melalui menu video call, 
grup WA dapat menjadi media alternatif literasi jaringan, terutama mahasiswa yang di daerah tempat tinggal kesulitan sinyal atau jaringan.

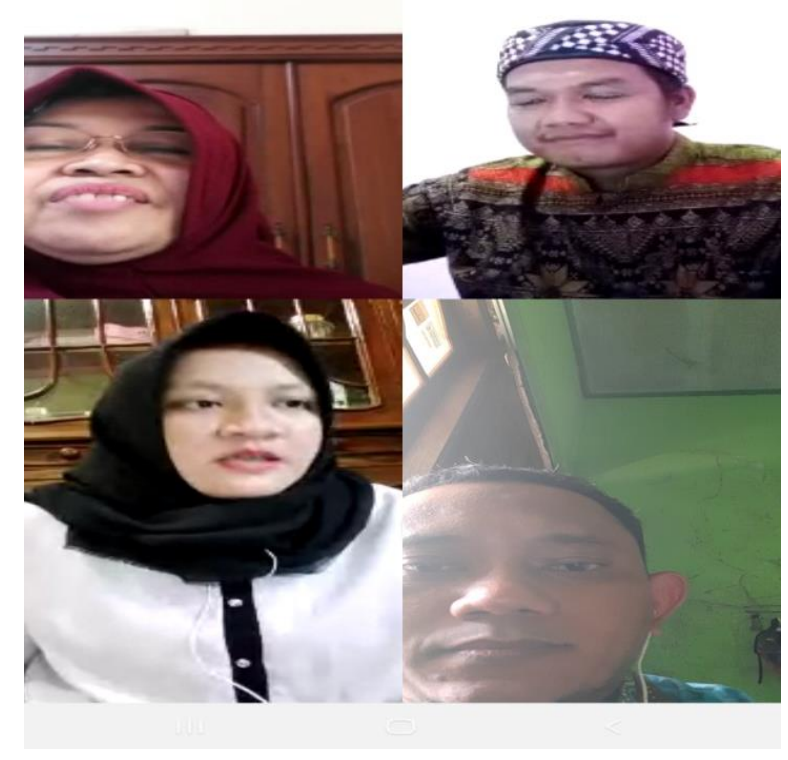

Gambar 3. Pemakaian Video Call Grup WA dalam Ujian Skripsi

Ketiga, strategi inovasi literasi jaringan digunakan dalam pelaksanaan pengajian dosen dan tenaga kependidikan (tendik) di lingkungan Universitas Ahmad Dahlan pada hari Senin, tanggal 24 Agustus 2020. Penceramah pengajian itu ialah Drs. H. Ahmad Dahlan Rais, M.Hum., dosen dari Universitas Muhammadiyah Surakarta (UMS). Melalui aplikasi Zoom, para dosen dan tendik di lingkungan UAD mengikuti ceramah dari adik kandung mantan Ketua Majelis Permusyawaratan Rakyat (MPR) Republik Indonesia itu. 


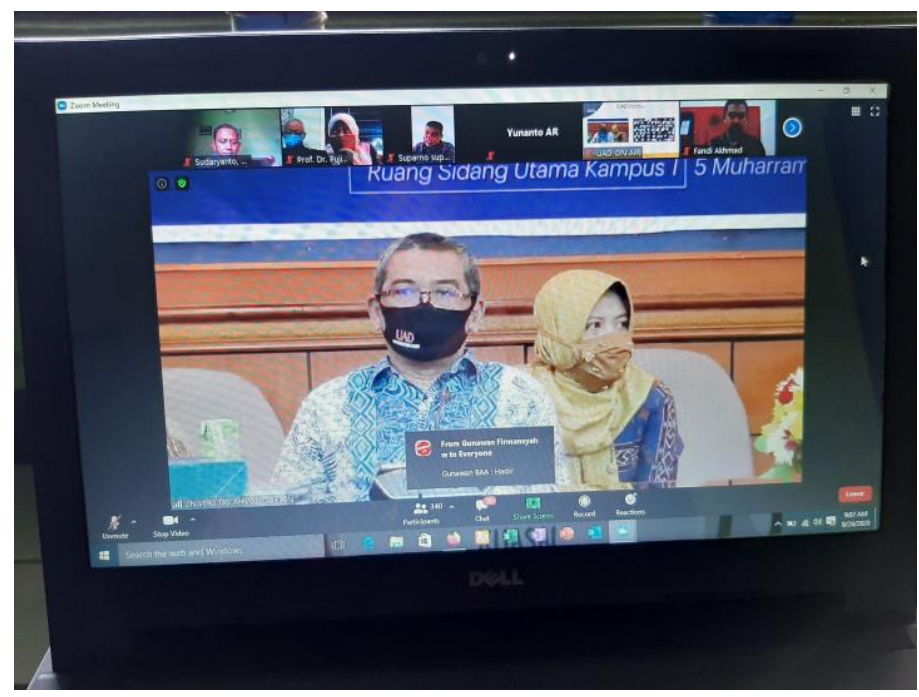

Gambar 4. Pengajian Dosen dan Tendik UAD Melalui Zoom

Keempat, strategi inovasi literasi jaringan digunakan dalam kegiatan pengabdian terhadap masyarakat. Salah satu dosen di Program Studi Pendidikan Bahasa dan Sastra Indonesia Fakultas Keguruan dan Ilmu Pendidikan Universitas Ahmad Dahlan menggunakan WA guna memberikan pelatihan menulis opini kepada anggota Musyawarah Guru Mata Pelajaran (MGMP) Bahasa Indonesia Madrasah Aliah (MA) DIY, dari tanggal 2 Mei hingga 5 Juni 2020.

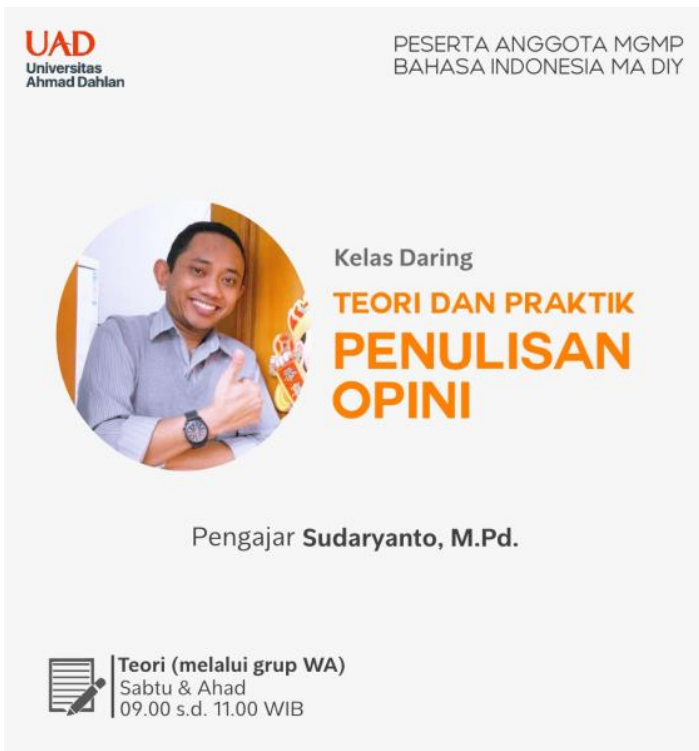

Gambar 5. Infografis Kegiatan Pengabdian terhadap Masyarakat

Kelima, strategi inovasi literasi jaringan digunakan dalam kegiatan kemahasiswaan. Pihak pengelola Program Studi Pendidikan Bahasa dan Sastra 
Indonesia Fakultas Keguruan dan Ilmu Pendidikan Universitas Ahmad Dahlan memiliki acara "PBSI Menyapa" secara rutin melalui Live Instagram akun $@$ pbsifkipuad. Pengisi acara itu adalah para dosen terkait bidang keilmuan masing-masing, seperti "Kesalahan Berbahasa Indonesia Tulis di Media Massa Daring” oleh Sudaryanto, M.Pd. yang menekuni bidang linguistik terapan. Melalui acara "PBSI Menyapa" itu, dosen dan mahasiswa, serta alumni PBSI FKIP UAD dapat saling berinteraksi satu sama lain melalui ruang obrolan (chat room) terkait tema tertentu.

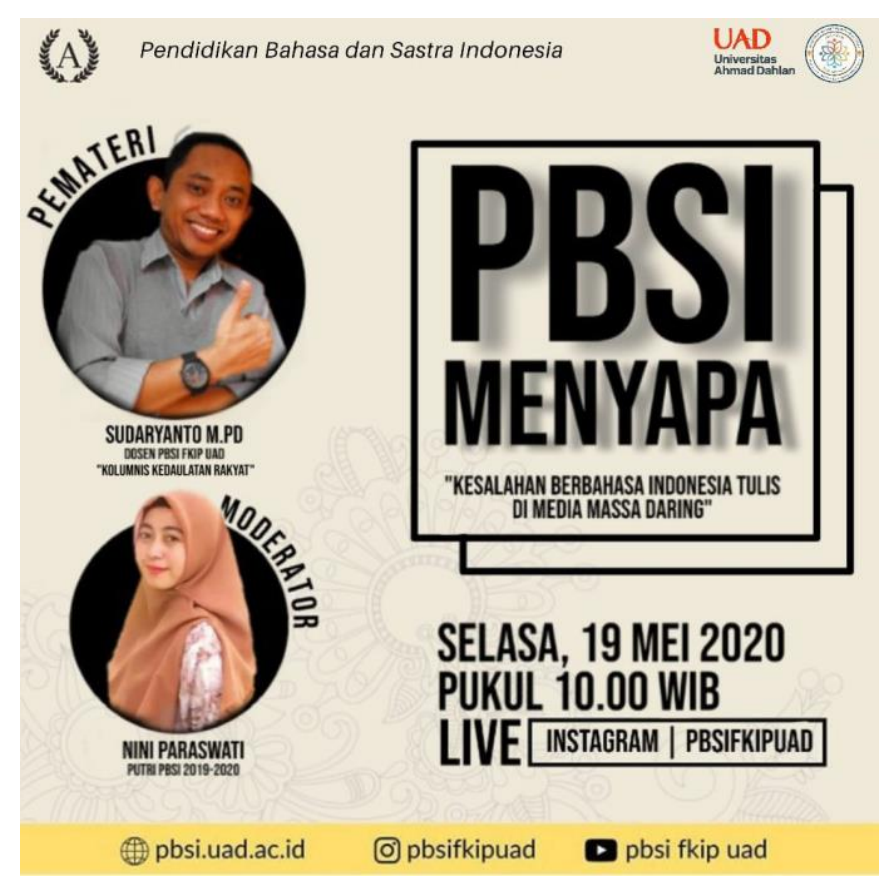

Gambar 6. Infografis Acara PBSI Menyapa Melalui Live Instagram

Keenam, strategi inovasi literasi jaringan digunakan dalam upaya pemberian dukungan terhadap salah satu finalis Duta Bahasa Daerah Istimewa Yogyakarta tahun 2020. Salah satu mahasiswa Program Studi Pendidikan Bahasa dan Sastra Indonesia Fakultas Keguruan dan Ilmu Pendidikan Universitas Ahmad Dahlan, yaitu Asri Mustika Aji, mengikuti ajang Pemilihan Duta Bahasa DIY tahun 2020. Para dosen dan mahasiswa Prodi PBSI FKIP UAD berikhtiar untuk mendukung Asri Mustika Aji melalui pengeklikan tanda cinta pada akun Instagram @dutabahasadiy. Dalam acara Malam Penobatan Duta Bahasa DIY 2020, Asri Mustika Aji memperoleh Terbaik III dalam hal program kerja di bidang kebahasaan dan kesastraan Indonesia. 


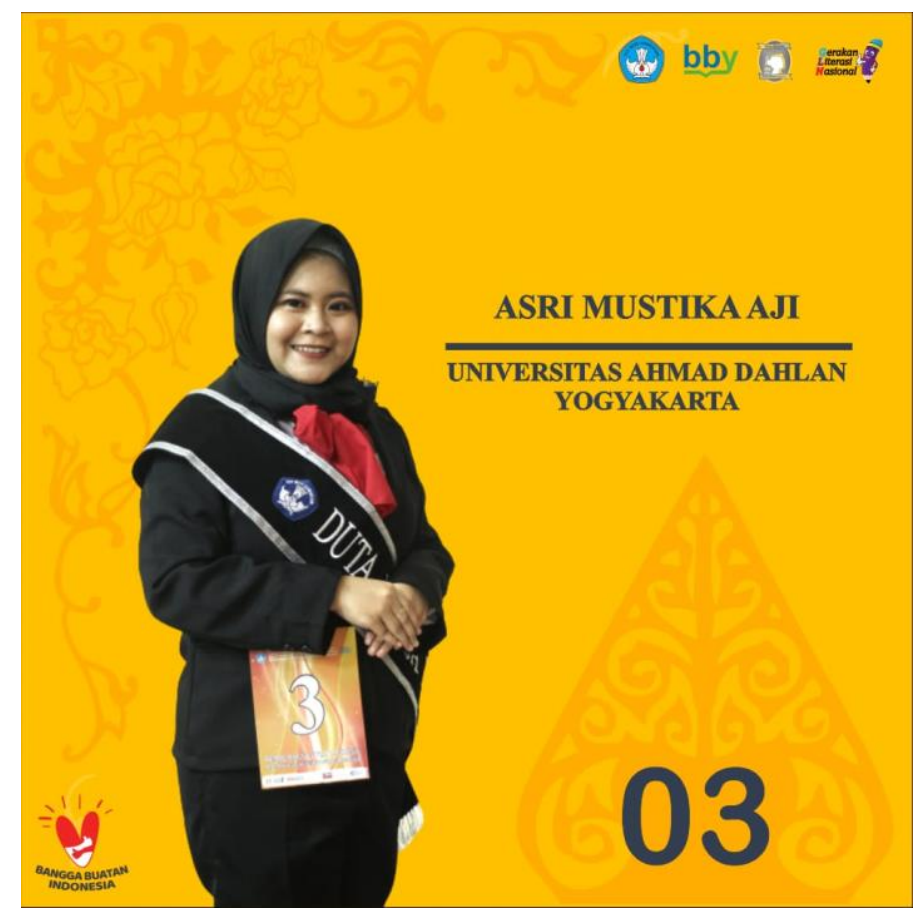

Gambar 7. Infografis Finalis Duta Bahasa DIY 2020 dari Universitas Ahmad Dahlan

\section{E. KESIMPULAN}

Berdasarkan uraian hasil dan pembahasan di atas, diperoleh sejumlah kesimpulan. Pertama, pihak dosen, mahasiswa, dan pengelola Program Studi Pendidikan Bahasa dan Sastra Indonesia Fakultas Keguruan dan Ilmu Pendidikan Universitas Ahmad Dahlan telah melaksanakan sejumlah strategi inovasi literasi jaringan dalam bidang pendidikan bahasa dan sastra Indonesia di tengah masa pandemi Covid-19. Kedua, strategi inovasi literasi jaringan terwujud dalam aktivitas perkuliahan melalui aplikasi WhatsApp, ujian skripsi melalui Zoom atau WhatsApp, pengajian dosen dan tenaga kependidikan di lingkungan UAD melalui Zoom, kegiatan pengabdian terhadap masyarakat melalui WhatsApp, kegiatan kemahasiswaan melalui Live Instagram @pbsifkipuad, dan upaya pemberian dukungan terhadap salah satu finalis Duta Bahasa DIY 2020 melalui Instagram @ dutabahasadiy. Ketiga, media-media daring, seperti WhatsApp, Zoom, Google Meet, dan Instagram menjadi sarana efektif dalam literasi jaringan di bidang pendidikan bahasa dan sastra Indonesia. 


\section{F. SARAN}

Ada dua saran terkait topik strategi literasi jaringan dalam bidang pendidikan bahasa dan sastra Indonesia di tengah masa pandemi Covid-19. Pertama, literasi jaringan bersifat sinkronis dan asinkronis sehingga pihak dosen dan mahasiswa dapat saling memahami satu sama lain. Literasi jaringan yang bersifat sinkronis itu terdapat pada media daring, seperti Zoom, Live Instagram, dan Google Meet, sedangkan literasi jaringan yang bersifat asinkronis itu terdapat pada media daring, seperti WhatsApp, e-learning, dan Google Classroom. Apabila mahasiswa mengalami kesulitan atau keterbatasan sinyal, maka pihak dosen lebih baik memilih literasi jaringan bersifat asinkronis.

Kedua, literasi jaringan, seperti kata-kata Chomsky di muka tulisan ini, bisa menjadi langkah yang sangat positif untuk memajukan pendidikan, organisasi, dan partisipasi dalam masyarakat, khususnya masyarakat Indonesia. Melalui literasi jaringan, masyarakat Indonesia, terutama generasi muda dan mahasiswa, kian sadar akan pentingnya kegiatan membaca dan menulis, serta menyaring informasi yang akurat. Di tengah-tengah fenomena tsunami informasi saat ini, literasi jaringan perlu terus ditumbuhkan dan dikembangkan kendatipun dalam kondisi terbatas karena masih dalam masa BDR lantaran pandemi Covid-19.

\section{DAFTAR PUSTAKA}

Agustien, Y. M., Prijana, P., \& Yanto, A. 2019, Relasi Kemampuan Literasi Jaringan dengan Manajemen Privasi Pelajar SMA Negeri 1 Sumedang. Pustakaloka, vol. 11, no. 1, hlm. 18-35.

Anggraeni, H., 2019, Penguatan Blended Learning Berbasis Literasi Digital dalam Menghadapi Era Revolusi Industri 4.0. Al-Idarah: Jurnal Kependidikan Islam, vol. 9, no. 2, hlm. 190-203.

Herlandy, P. B. \& Novalia, M., 2019, Penerapan E-Learning pada Pembelajaran Komunikasi dalam Jaringan dengan Metode Blended Learning bagi Siswa SMK. Journal of Education Informatic Technology and Science, vol. 1, no. 1, hlm. 24-33.

Jordana, T. A. \& Suwarto, D. H., 2017, Pemetaan Gerakan Literasi Digital di Lingkup Universitas Negeri Yogyakarta. Informasi, vol. 47, no. 2, hlm. 167180. 
Kridalaksana, H., 2011, Kamus Linguistik Edisi Keempat, Gramedia Pustaka Utama, Jakarta.

Moleong, L. J., 1988, Metode Penelitian Kualitatif. Depdikbud, Jakarta.

Mulyono, D. \& Ansori, A., 2020, Literasi Informasi dalam Kerangka Pengembangan Pendidikan Masyarakat. Comm-Edu (Community Education Journal), vol. 3, no. 1, hlm. 1-6.

Mustafa, S. E., 2013, Media Sosial di Malaysia dan Indonesia: Penggunaannya sebagai Alat Komunikasi, Kolaborasi, dan Jaringan Digital. Jurnal Pengajian Media Malaysia, vol. 15, no. 2, hlm. 71-85.

Pattah, S. H., 2014, Literasi Informasi: Peningkatan Kompetensi Informasi dalam Proses Pembelajaran. Khizah al-Hikmah: Jurnal Ilmu Perpustakaan, Informasi, dan Kearsipan, vol. 2, no. 2, hlm. 108-119.

Rahayu, T., Mayasari, T., \& Huriawati, F., 2019, Pengembangan Media Website Hybrid Learning Berbasis Kemampuan Literasi Digital dalam Pembelajaran Fisika. Jurnal Pendidikan Fisika, vol. 7, no. 1, hlm. 130-142.

Riady, Y., 2013, Literasi Informasi Sejak Dini: Pengetahuan Baru bagi Anak Usia Dini. Jurnal Ilmiah Visi, vol. 8, no. 2, hlm. 159-165.

Said, I., 2016, Literasi Informasi: Perspektif Pustakawan. Jupiter, vol. 15, no. 1, hlm. 10-15.

Siyamitri, P., 2015, Literasi Media Internet pada Kalangan Guru Sekolah Menengah Kejuruan di Kota Medan. Jurnal Simbolika: Research and Learning in Communication Study, vol. 1, no. 2, hlm. 161-176.

Subarjo, A. H., 2017, Perkembangan Teknologi dan Pentingnya Literasi Informasi untuk Mendukung Ketahanan Nasional. Angkasa: Jurnal Ilmiah Bidang Teknologi, vol. 11, no. 2, hlm. 1-8.

Sudaryanto, S., Hermanto, H., \& Wijayanti, D., 2018, Wacana Padanan Istilah Asing-Indonesia dan Kaitannya dengan Pembelajaran Bahasa Indonesia bagi Penutur Asing (BIPA). Jurnal Pesona, vol. 4, no. 2, hlm. 1-9.

Sudaryanto, S., Lestari, A. T., \& Anggita, F. D., 2019a, Pembinaan Bahasa Indonesia: Bagaimana Strateginya di Era Digital? Jurnalistrendi: Jurnal Linguistik, Sastra, dan Pendidikan, vol. 4, no. 1, hlm. 269-278.

Sudaryanto, S., Hermanto, H., \& Gustiani, E. L., 2019b, Media Sosial sebagai Sarana Pembinaan Bahasa Indonesia di Era Digital. Kode: Jurnal Bahasa, vol. 8 , no. 4 , hlm. 61-74. 